\title{
Sequential versus simultaneous auctioning of procurement contracts with common value and private value components
}

Citation for published version (APA):

De Silva, D., Pagel, B., \& Peeters, R. J. A. P. (2008). Sequential versus simultaneous auctioning of procurement contracts with common value and private value components. METEOR, Maastricht University School of Business and Economics. METEOR Research Memorandum No. 005 https://doi.org/10.26481/umamet.2008005

Document status and date:

Published: 01/01/2008

DOI:

10.26481/umamet.2008005

Document Version:

Publisher's PDF, also known as Version of record

\section{Please check the document version of this publication:}

- A submitted manuscript is the version of the article upon submission and before peer-review. There can be important differences between the submitted version and the official published version of record. People interested in the research are advised to contact the author for the final version of the publication, or visit the DOI to the publisher's website.

- The final author version and the galley proof are versions of the publication after peer review.

- The final published version features the final layout of the paper including the volume, issue and page numbers.

Link to publication

\footnotetext{
General rights rights.

- You may freely distribute the URL identifying the publication in the public portal. please follow below link for the End User Agreement:

www.umlib.nl/taverne-license

Take down policy

If you believe that this document breaches copyright please contact us at:

repository@maastrichtuniversity.nl

providing details and we will investigate your claim.
}

Copyright and moral rights for the publications made accessible in the public portal are retained by the authors and/or other copyright owners and it is a condition of accessing publications that users recognise and abide by the legal requirements associated with these

- Users may download and print one copy of any publication from the public portal for the purpose of private study or research.

- You may not further distribute the material or use it for any profit-making activity or commercial gain

If the publication is distributed under the terms of Article $25 \mathrm{fa}$ of the Dutch Copyright Act, indicated by the "Taverne" license above, 
Dakshina De Silva, Beatrice Pagel,

Ronald Peeters

Sequential versus Simultaneous Auctioning of Procurement Contracts with Common Value and Private Value Components

$\mathrm{RM} / 08 / 005$

JEL code: D44, H57

\section{METEबrR}

Maastricht research school of Economics of TEchnology and ORganizations

Universiteit Maastricht

Faculty of Economics and Business Administration P.O. Box 616

NL - 6200 MD Maastricht

phone : ++31433883830

fax : ++31433884873 


\title{
Sequential versus Simultaneous Auctioning of Procurement Contracts with Common Value and Private Value Components*
}

\author{
Dakshina De Silva ${ }^{\dagger} \quad$ Beatrice Pagel ${ }^{\ddagger} \quad$ Ronald Peeters $^{\S}$
}

March 2008

\begin{abstract}
We study procurement auctions held in sequential and simultaneous formats. For the latter format, we find less bid participation and more aggressive bidding for projects with strong common value components and more competition for projects having strong private value components.

JEL classification: D44; H57.
\end{abstract}

Keywords: Procurement auctions.

\section{Introduction}

In an effort to reduce operational costs, the Oklahoma Department of Transportation (ODOT) decided in March 2002 to change the design of their monthly procurement auctions for road construction contracts. Until this date, ODOT auctioned off the contracts in two separate sessions on a single day, with half of the contracts being simultaneously auctioned in the morning (AM) and the other half in the afternoon (PM). Prior to the PM-auctions, all submitted bids in the AM-auctions were publicly revealed. Since this date, all projects were auctioned simultaneously in one single session.

Ortega Reichert (1968) and Hausch (1986) both study a two-bidder, two-period, sequential first-price sealed-bid procurement auction where bidders demand more than one object and learn all first period bids prior to the second period. Ortega Reichert (1968) studies the case where at the beginning of each period, bidders are privately informed about their costs for the contracts, which are independently drawn from an exponential distribution with unknown

${ }^{*}$ Financing by METEOR (Maastricht research school of Economics of TEchnology and ORganizations) and NWO is gratefully acknowledged.

${ }^{\dagger}$ Department of Economics, Texas Tech University, Lubbock, TX 79409-1014, USA. E-mail: dakshina.desilva@ttu.edu.

${ }^{\ddagger}$ Student MSc IES, Universiteit Maastricht, The Netherlands. E-mail: bea_pagel@hotmail.com.

${ }^{\S}$ Department of Economics, Universiteit Maastricht, P.O. Box 616, 6200 MD, Maastricht, The Netherlands. E-mail: R.Peeters@algec.unimaas.nl. Corresponding author. 
parameter. He shows that there is a 'deception effect'. That is, he finds that each bidder has an incentive to bid less aggressively in the first auction, compared to a one-shot auction, in order to induce the rival to hold a more pessimistic belief about the unknown parameter. Hausch (1986) studies the case with a common cost for the two identical objects, but where the two bidders receive different estimates about the true cost. Besides the deception effect, he shows there is an 'informational effect' that leads to more aggressive bidding in the second period, compared to a one-shot auction.

Li and Zheng (2006) and De Silva et al. (2007) study the effect of endogenous auction entry on bidding behavior. The first concentrates on the IPV setting only; the second on the more general affiliated value setting, for which the IPV and CV setting are the polar cases. In line with the contestable markets literature, these papers find the negative 'competition effect' (more actual bidders increase bid aggression) and the positive 'entry effect' (more potential bidders lead to less actual bidders).

Using the data from January 1997 to June 2004, we evaluate the impact of the design change on bidding participation and bidding behavior. Like the distinction often made in the theoretical literature, we distinguish between projects having a strong common value component and those having a strong private value component. We find that for the first type, the policy change has triggered more aggressive bidding behavior, but a decrease in the probability to submit a bid (without decreasing the total number of bidders). For the latter type, we find that only the number of bidders has increased. These results have the potential to observe a decrease in procurement costs for both project types. However, the tests do not lend strong support for this potential observation.

\section{Data}

Roughly one month prior to the auction letting, bidders learn the detailed project description, the estimated completion time, the engineering cost estimates (ECE) and the plan holder list (the list of potential bidders). Apart from the design change implemented in March 2002, there are no further design differences among auctions held in the period between April 2000 and June 2004. ${ }^{1}$ We use data from January 1997 to March 2000 to create variables based on bidder history such as capacity utilization and potential rivals' capacity commitment. Data from April 2000 to June 2004 are used to analyze the empirical models. For each project, we know the plan holders, all bids submitted, the winning bid and the winner. These data were gathered from the plan holder list, as read bid report, low bid report, and award notices that are posted on the ODOT website.

\footnotetext{
${ }^{1}$ The ECE are only revealed since April 2000.
} 
This unique natural experiment allows us to evaluate the impact of the design change on bidding participation and behavior. We do this for auctions having a strong private value component and those having a strong common value component separately. Following De Silva et al. (2008), we categorize asphalt work as projects having a large private value component and bridge work as projects having a strong common value component.

Table 1 summarizes for the two different project types (asphalt and bridge), the number of auctions, the average number of plan holders per auction, average number of bidders per auction, and the average bid relative to the ECE.

\begin{tabular}{lcccccc}
\hline Variable & \multicolumn{2}{c}{$\begin{array}{c}\text { AM-auctions } \\
\text { before March 2002 }\end{array}$} & \multicolumn{2}{c}{$\begin{array}{c}\text { PM-auctions } \\
\text { before March 2002 }\end{array}$} & \multicolumn{2}{c}{$\begin{array}{c}\text { Auctions } \\
\text { after March 2002 }\end{array}$} \\
\cline { 2 - 7 } & Asphalt & Bridge & Asphalt & Bridge & Asphalt & Bridge \\
\hline Number of auctions & 93 & 172 & 87 & 153 & 294 & 348 \\
Number of plan holders & 3.828 & 6.081 & 4.149 & 6.150 & 4.578 & 7.000 \\
per auction & $(1.810)$ & $(2.576)$ & $(2.003)$ & $(2.628)$ & $(2.467)$ & $(2.813)$ \\
Number of bidders & 2.419 & 3.663 & 2.770 & 3.732 & 2.755 & 3.925 \\
per auction & $(1.393)$ & $(1.774)$ & $(1.344)$ & $(1.846)$ & $(1.380)$ & $(1.708)$ \\
Relative bid & 1.050 & 1.075 & 1.045 & 1.046 & 1.061 & 1.038 \\
& $(0.195)$ & $(0.270)$ & $(0.212)$ & $(0.366)$ & $(0.169)$ & $(0.408)$ \\
\hline
\end{tabular}

Table 1: Summary statistics.

Standard deviations are in brackets.

\section{$3 \quad$ Empirical model and results}

First, we test how the design change has affected bidding behavior in Oklahoma. Our econometric specification, allowing for differential effects across the three time periods, is

$$
\operatorname{rbid}_{i a t}=\alpha_{i}+\beta_{1} D_{t}^{P M}+\beta_{2} D_{t}^{\text {Sim }}+X \Gamma+\varepsilon_{i a t},
$$

where the unit of observation is firm $i$ bidding in auction $a$ in time period $t$. The relative bid (bid/ECE) is used as the dependent variable throughout this analysis. The independent variables include controls for the change in the timing of auctions, variables on auction characteristics, bidder characteristics, rival characteristics and characteristics of the business environment. $\beta_{1}$ measures the difference in bidding in PM-auctions relative to AM-auctions. $\beta_{2}$ captures the difference in bidding between simultaneous auctions and AM-auctions.

We use an auction-level variable - the expected number of bidders - to control for bidding competition. $^{2}$ Moreover, we include two variables that measure bidder cost heterogeneity in addition to firm fixed effects: bidder's capacity utilization rate and bidder's distance to a project. In order to control for bidder experience, we include dummies to identify new

\footnotetext{
${ }^{2}$ This variable is constructed in a similar manner as in Hendricks et al. (2003).
} 
bidders in the market and 'incumbents' facing these 'entrants'. ${ }^{3}$ When controlling for rival characteristics, we include the rivals' minimum distance to the project and the minimum backlog. ${ }^{4}$ Finally, we control for the business environment using four variables. ${ }^{5}$

All models are estimated with robust standard errors. The fixed effects models are estimated with firm fixed effects to control for bidder heterogeneity. Here, we use only multiple bids submitted by bidders. The standard errors reported are cluster-robust where the clustering is on firms.

The key parameters of interest in Table 2 are $\beta_{1}$ and $\beta_{2}$. The OLS results indicate that for bridge work, bidders bid more aggressively in PM-auctions and in simultaneous auctions relative to AM-auctions. For winning bids and bids when controlled for bidder heterogeneity, we observe similar results, though there is weak support for aggressive bidding in simultaneous settings. For asphalt work, we do not observe any statistical difference among the auctions in the sequential (AM and PM) and simultaneous format.

\begin{tabular}{lcccccc}
\hline Variable & \multicolumn{3}{c}{ OLS } & \multicolumn{2}{c}{ With firm effects } \\
\cline { 2 - 7 } & \multicolumn{3}{c}{ Bids } & \multicolumn{2}{c}{ Winning bids } & \multicolumn{2}{c}{ Bids } \\
\cline { 2 - 7 } & Asphalt & Bridge & Asphalt & Bridge & Asphalt & Bridge \\
& $(1)$ & $(2)$ & $(3)$ & $(4)$ & $(5)$ & $(6)$ \\
\hline PM bids $\left(\beta_{1}\right)$ & -.015 & $-.043^{* *}$ & -.027 & $-.051^{*}$ & .001 & $-.039^{*}$ \\
& $(.019)$ & $(.018)$ & $(.022)$ & $(.029)$ & $(.018)$ & $(.023)$ \\
Bids after & .016 & $-.057^{* *}$ & .031 & -.044 & .008 & -.016 \\
March 2002 $\left(\beta_{2}\right)$ & $(.025)$ & $(.026)$ & $(.030)$ & $(.040)$ & $(.032)$ & $(.051)$ \\
\hline \# of obs. & 1275 & 2565 & 396 & 589 & 1257 & 2531 \\
Adj. $R^{2}$ & .070 & .093 & .045 & .018 & .053 & .040 \\
$p$-value for $\beta_{1}=\beta_{2}$ & .221 & .616 & $.063^{*}$ & .871 & .818 & .704 \\
\hline
\end{tabular}

Table 2: Regression results for relative bids and relative winning bids.

** denotes statistical significance at the $5 \%$ level and * at the $10 \%$ level. All regressions include controls for auction, bidder, rivals, and business characteristics. In columns (1) and (2) we have included bidder experience dummies and bidder experience dummies interacted with PM and after March 2002 dummies.

Besides individual bidding behavior, the design change may have affected bidder participation and bid submission. Table 3 displays Poisson results for participation, the Probit results for bid submission, and the probability of winning conditional upon bidding. We observe that, after the policy change in March 2002, the number of potential bidders has

\footnotetext{
${ }^{3}$ These variables are similar to the ones used in De Silva et al. (2003).

${ }^{4}$ These variables are similar to variables used in Bajari and Ye (2003), Jofre-Bonet and Pesendorfer (2000) and De Silva et al. (2005).

${ }^{5}$ The first is the monthly, seasonally unadjusted, state-level unemployment rate for Oklahoma, gathered from the US Bureau of Labor Statistics. Next, we use the three-month average of the real volume of projects, constructed from the ECE. In addition, we consider the state-specific three-month average of the number of building permits collected from the US Bureau of Economic Analysis. These controls have also been used in De Silva et al. (2008).
} 
increased for asphalt and bridge work. However, the number of actual bidders increased only for asphalt work. We find no statistically significant difference in bidder participation between AM- and PM-auctions. Moreover, we observe that the probability of bidding upon being plan holder has decreased for bridge projects. Again, we find no statistically significant differences between AM- and PM-auctions.

\begin{tabular}{lcccccccc}
\hline Variable & \# of plan holders & \multicolumn{3}{c}{ \# of bidders } & \multicolumn{2}{c}{ Bid submission } & \multicolumn{2}{c}{$\begin{array}{c}\text { Winning cond. } \\
\text { upon bidding }\end{array}$} \\
\cline { 2 - 9 } & Asphalt & Bridge & Asphalt & Bridge & Asphalt & Bridge & Asphalt & Bridge \\
& $(1)$ & $(2)$ & $(3)$ & $(4)$ & $(5)$ & $(6)$ & $(7)$ & $(8)$ \\
\hline PM bids $\left(\beta_{1}\right)$ & .044 & -.062 & .078 & -.056 & .028 & .005 & -.005 & .018 \\
& $(.253)$ & $(.263)$ & $(.200)$ & $(.177)$ & $(.037)$ & $(.023)$ & $(.043)$ & $(.025)$ \\
Bids after & $1.395^{* *}$ & $1.341^{* *}$ & $.698^{* *}$ & .237 & -.050 & $-.063^{* *}$ & -.088 & -.011 \\
March 2002 $\left(\beta_{2}\right)$ & $(.323)$ & $(.371)$ & $(.220)$ & $(.252)$ & $(.048)$ & $(.031)$ & $(.058)$ & $(.034)$ \\
\hline \# of Obs. & 389 & 589 & 396 & 589 & 2063 & 4421 & 1275 & 2565 \\
Wald $\chi^{2}$ & 316.26 & 255.62 & 148.37 & 194.47 & 65.40 & 79.52 & 34.36 & 34.65 \\
\hline
\end{tabular}

Table 3: Participation patterns and bid submission results.

** denotes statistical significance at the $5 \%$ level and * at the $10 \%$ level. For the regressions in columns (1)-(4) we use only auction and business condition variables; for columns (5)-(8) we included firm and rivals characteristics in addition to auction and business level variables.

\section{Conclusion}

In this paper we investigate the impact of the latest design change in the ODOT procurement auctions on bidding participation and behavior for projects having a strong private value component and those having a strong common value component. We find that for the latter project type, the policy change has triggered more aggressive bidding behavior and decreased the probability on auction entry among potential bidders. These results are in line with Hausch (1986) and De Silva et al. (2007).

\section{References}

Bajari, P., Ye, L., 2003. Deciding between competition and collusion. Review of Economics and Statistics 85, 971-989.

De Silva, D.G., Dunne, T., Kankanamge, A., Kosmopoulou, G., 2008. The impact of public information on bidding in highway procurement auctions. European Economic Review 52, 150-181.

De Silva, D.G., Dunne, T. and Kosmopoulou, G., 2003. An empirical analysis of entrants and incumbents bidding in road construction auctions. Journal of Industrial Economics 51, 
295-316.

De Silva, D.G., Jeitschko, T.D, and Kosmopoulou, G., 2005. Stochastic synergies in sequential auctions. International Journal of Industrial Organization 23, 183-201.

De Silva, D.G., Jeitschko, T.D, and Kosmopoulou, G., 2007. Optimal bidding behavior under common and private values in auctions with an unknown number of rivals due to endogenous entry. Mimeo.

Hausch, D., 1986. Multi-object auctions: Sequential vs. simultaneous sales. Management Science 32, 1599-1610.

Hendricks, K., Pinkse, J., Porter, R.H., 2003. Empirical implications of equilibrium bidding in first-price, symmetric, common value auctions. Review of Economic Studies 70, 115-45.

Jofre-Bonet, M., Pesendorfer M., 2000. Bidding behavior in a repeated procurement auction: A summary. European Economic Review 44, 1006-1020.

Li, T., Zheng, X., 2006. Entry and competition effects in first-price auctions: Theory and evidence from procurement auctions. CeMMAP working paper CWP13/06.

Ortega Reichert, A., 1968. A sequential game with information flow. Chapter VIII of PhD thesis, Stanford University. Reprinted in: Klemperer, P.D. (Ed.), 2000. The Economic Theory of Auctions, vol. 1, Edward Elgar, Cambridge, UK, pp. 130-152. 